\title{
Analisis Perubahan Struktur Ekonomi Dan Sektor Unggulan Kota Kendari Tahun 2010-2020
}

\author{
Andriani Puspitaningsih ${ }^{1}$, Asri Djauhar ${ }^{2}$, Teguh Permana ${ }^{3}$ \\ ${ }^{13}$ Universitas Halu Oleo, Indonesia \\ ${ }^{2}$ Universitas Sulawesi Tenggara, Indonesia \\ ${ }^{1}$ andrianipuspitaningsih@uho.ac.id
}

\begin{abstract}
This study aims to determine changes in the structure and leading sectors in the City of Kendari. This research is a quantitative research using secondary data from BPS in the form of GRDP of Kendari city based on the business field in 2010-2020. The results showed that the economic structure of the city of Kendari is dominated by the retail wholesale trade sector and the construction sector. Where in 2010 the trade sector gave the largest contribution to GRDP, but in 2020 the construction sector dominates the contribution to GRDP. The results of other studies show that the leading sector in the city of Kendari is the corporate services sector from 2010-2020. The implication of the results of this study is that the city of Kendari as a service city needs to make changes to urban planning related to trade. And as a city that has advantages in the service sector, it is necessary to issue policies that support service improvement in order to increase the value of the contribution of the service sector in the city of Kendari considering that the city of Kendari is not superior in terms of agriculture.
\end{abstract}

Keywords: GRDP, $L Q$

\begin{abstract}
Abstrak
Penelitian ini bertujuan untuk mengetahui perubahan struktur dan sektor unggulan di Kota Kendari. Penelitian ini merupakan penelitian kuantitatif dengan menggunakan data sekunder dari BPS berupa PDRB kota Kendari berdasarkan lapangan usaha tahun 2010-2020. Hasil penelitian menunjukkan bahwa struktur ekonomi kota Kendari di dominasi oleh sektor perdagangan besar eceran dan sektor konstruksi. Dimana pada tahun 2010 sektor perdagangan memberi kontribusi terbesar pada PDRB, namun tahun 2020 sektor konstruksi mendominasi kontribusi terhadap PDRB. Hasil penelitian yang lain menunnjukkan bahwa sektor unggulan di kota Kendari adalah sektor jasa-jasa perusahaan sejak tahun 2010-2020. Implikasi dari hasil penelitian tersebut bahwa kota Kendari sebagai kota jasa perlu melakukan perubahan pada tata kota yang berhubungan dengan perdagangan. Dan sebagai kota yang memiliki keunggulan di sektor jasa maka perlu dikeluarkan kebijakan yang mendukung peningkatan pelayanan dalam rangka peningkatan nilai kontribusi sektor jasa di kota Kendari mengingat kota Kendari tidak unggul dari sisi pertanian.
\end{abstract}

Kata Kunci: PDRB, LQ

\section{Pendahuluan}

Pembangunan ekonomi terus dilakukan di setiap negara di dunia dengan tujuan akhir untuk meningkatkan kesejahteraan masyarakat. Pertumbuhan ekonorni yang terus tumbuh walaupun fluktuatif di seluruh dunia tetapi yang terpenting tetap terjadi pertumbuhan. Pembangunan mengandung arti suatu proses yang menyebabkan sesuatu 
dapat tumbuh atau menjadi lebih matang atau dewasa (Homby, 1989 dalam Ruda, 2015). Saat ini, buku-buku yang membahas pembangunan ekonomi di negara-negara berkembang sudah beranjak dari focus perhatian dari hanya pertumbuhan menuju pertumbuhan, pemerataan dan keadilan, kualitas hidup bahkan lingkungan sekitar (Meier, 2005 dalam Ruda, 2015). Jhingan dalam Purba dkk dikatakan bahwa adanya tahapan konsep pembangunan yang dikembangkan di Indonesia yaitu strategi pertumbuhan, pertumbuhan dan distribusi, teknologi tepat guna, kebutuhan dasar, pembangunan berkelanjutan dan pemberdayaan.

Di Indonesia juga terus dilakukan pembangunan ekonomi terntama di sektor infrastruktur selama 5 tahun terakhir. Akibat dari pembangunan ekonomi tersebut maka terjadi pertumbuhan pada tahun 2019 sebesar 5,02\% dan 5,17\% pada tahun 2018. Todaro \& Smith (2003) dalam Arsyad (2017) menyatakan bahwa keberhasilan pembangunan ekonomi suatu negara ditunjukkan oleh tiga nilai pokok yaitu (1) berkembangnya kemampuan masyarakat untuk memenuhi kebutuhan pokoknya (sustenance), (2) meningkatnya rasa harga diri (self-esteem) masyarakat sebagai manusia, dan (3) meningkatnya kemampuan masyarakat untuk memilih (freedom from servitude) yang merupakan salah satu dari hak asasi manusia. Menurut Lewis dalam Jhingan (2013), pendorong utama pertumbuhan ekonomi ialah upaya berhemat (ekonomis), peningkatan pengetahuan dan penerapannya di bidang produksi dan peningkatan jumlah modal atau sumber lain per kepala (Ruda, 2015).

Pertumbuhan selalu identik dengan pembangunan ekonomi, ketika dilakukan pembangunan ekonomi maka akan diharapkan terjadinya pertumbuhan ekonomi yang besar sehingga dapat menciptakan kesejahteraan di masyarakat. Pembangunan ekonomi juga terjadi di berbagai wilayah di Indonesia khususnya di provinsi Sulawesi tenggara dengan 17 kabupaten/kota Pada tahun 2018 ekonomi Sulawesi tenggara tumbuh 6,42\% dan 6,87\% pada kuartal 4 tahun 2019.

Pembangunan ekonomi juga terjadi di Kota Kendari yang pada tahun 2011 terjadi pertumbuhan 10,26\% menurun pada tahun 2019 6,48\%. Dan pada tahun 2020 menjadi $1,30 \%$ akibat dari adanya pandemi covid19. Salah satu aspek dalam pembangunan ekonomi yang sangat penting yaitu bagaimana mengelola sumber daya alam secara efektif dan efisien (Junaidi dan Zulgaini, 2011). Menurut Darwanto (2002) bahwa setiap daerah mempunyai corak pertumbuhan ekonomi yang berbeda dengan daerah lain. Oleh sebab itu perencanaan pembangunan ekonomi suatu daerah pertama-tama perlu mengenali karakter ekonomi, sosial dan fisik daerah itu sendiri, termasuk interaksinya dengan daerah lain. Dengan demikian tidak ada strategi pembangunan ekonomi daerah yang dapat berlaku untuk semua daerah.

Kota Kendari sebagaimana kota-kota besar lainnya menawarkan jasa-jasa, perdagangan dan konstruksi, berbeda dengan kabupaten lainnya di Sulawesi tenggara yang masih cenderung bersifat agraris. Kota Kendari sebagai wilayah yang paling berkembang diantara daerah lain. Kota Kendari sebagai ibu kota provinsi Sulawesi tenggara telah banyak terutama sektor knstruksi. Telah banyak perkembangan diantaranya berdirinya Lippo Mall, pasar-pasar telah di remajakan menjadi lebih modern, jalan diperlebar dan yang terakhir akan dibangun transtudio. Tentu masih banyak jasa-jasa lainnya yang turut berkembang yang didukung oleh semakin bertambahnya penduduk kota Kendari yang merupakan pasar bagi sektor jasa dan secara langsung meningkatkan permintaan akan hunian.

Anggaran yang terbatas membuat pemerintah harus membuat skala prioritas dalam melakukan pembangunan ekonomi, apalagi situasi pandemi sekarang yang membuat anggaran harus dialokasikan pada penanggulangan pandemi covid19. Titik awal yang 
harus dilakukan ialah mengidentifikasi kembali struktur ekonomi kota Kendari kemudian melihat sektor unggulan agar prioritas anggaran dapat di maksimalkan sehingga apa yang diharapkan dalam perencanaan dapat terlaksana dengan baik. Dalam Sjafrizal (2015) dikatakan bahwa analisis tentang struktur ekonomi daerah diperlukan dalam penyusunan perencanaan pembangunan daerah sebagai dasar untuk menentukan arah umum pembangunan daerah. Bila struktur perekonomian suatu daerah didominasi oleh kegiatan pertanian (agraris), maka arah pembangunan juga disesuaikan dengan struktur perekonomian daerah tersebut.

\section{Metode}

Metode penelitian yang digunakan menggunakan desain penelitian kuantitatif. Dengan menggunakan data sekunder dari BPS yaitu PDRB Kota Kendari dan Sulawesi Tenggara tahun 2010-2020. Alat analisis yang digunakana untuk melihat struktur ekonomi yaitu dengan menghitung kontribusi masing-masing sektor dalam nilai PDRB daerah Kota Kendari berdasarkan harga berlaku. Dengan rumus (Sjafrizal,2015) sebagai berikut:

Nilai tambah sektor i

Kontribusi sektor $\mathrm{I}=-\quad$ Jumlah nilai PDRB $\times 100 \%$

Sedangkan untuk melihat sektor unggulan digunakan analisis location quotient (LQ) dengan rumus

$\frac{\stackrel{s i}{\mathrm{PDRB}}}{\underline{\mathrm{Si}}} \quad \mathrm{PQ}=$

Dimana LQ adalah Location Quotient, Si adalah nilai tambah sektoral (i) secara regional, PDRB adalah produk domestik regional bruto, Si adalah nilai tambah sektoral (i) secara nasional, PDB adalah produk domestik bruto (Harafah, 10). Location quotient (LQ) adalah salah satu dari perangkat analisis ekonomi yang di gunakan untuk melihat sektor unggulan di suatu wilayah atau biasa juga disebut sektor basis. Analisis ini juga digunakan untuk mengetahui sejauh mana tingkat spesialisasi sektor-sektor ekonomi di suatu daerah atau sektor-sektor apa saja yang merupakan leading sektor. Hasil perhitungan LQ dapat dijabarkan sebagai berikut: Jika LQ > 1 maka dapat dikatakan bahwa produk / komoditas tersebut adalah basis yang berarti sektor tersebut unggul, Jika LQ $<1$ maka dapat dikatakan bahwa produk / komoditas tersebut adalah non basis yang berarti sektor tersebut tidak unggul, sedangkan jika $\mathrm{LQ}=1$ maka dapat dikatakan bahwa produk/komoditas tersebut adalah unitary yang berarti sector tersebut hanya cukup untuk wilayah yang bersangkutan, tidak bias di ekspor dan juga tidak memerlukan impor.

\section{Hasil dan Pembahasan}

Kota Kendari merupakan ibukota Provinsi Sulawesi Tenggara, secara astronomis terletak di bagian selatan garis khatulistiwa berada di antara $3^{\circ} 54^{\prime} 40^{\prime \prime}$ - 4 ${ }^{\circ} 5^{\prime} 5^{\prime \prime}$ LS dan $122^{\circ} 26^{\prime} 33^{\prime \prime}$ - 122 39'14" BT. Wilayah Kota Kendari berbatasan dengan Kabupaten Konawe di sebelah utara, Kabupaten Konawe Selatan di sebelah selatan dan barat, dan Laut Kendari di sebelah timur. Kota Kendari terdiri dari 10 kecamatan yaitu Kecamatan Mandonga, Kecamatan Baruga, Kecamatan Puuwatu, Kecamatan Kadia, Kecamatan Wua-wua, Kecamatan Poasia, Kecamatan Abeli, Kecamatan Kambu, Kecamatan Kendari, dan Kecamatan Kendari Barat. Kota Kendari memiliki tipologi tanah yang terdiri dari 14 jenis tanah diantaranya aluvial, glisol, litosol, dan podsolik sehingga 
menguntungkan bagi kegiatan pertanian, perkebunan, konstruksi, perikanan, dan lain-lain (perkotaan.bpiw.pu.go.id).

Kota Kendari seperti ibukota lainnya cenderung menjadi kota jasa karena memang karakteristiknya seperti itu beda dengan daerah lain yang ada di provinsi Sulawesi tenggara yang memiliki hasil pertambangan dan pertanian seperti aspal di buton, nikel di hampir Sebagian daerah yang ada di provinsi Sulawesi tenggara, bahkan emas pun dimiliki oleh daerah ini. Namun itu semua berada di wilayah luar kota Kendari. Dari sisi pariwisata kota Kendari memiliki beberapa objek wisata menarik diantaranya pulau bokori, pantai nambo, taman kota, kendari beach, kampung bakau. Kendari juga menjadi kota transit untuk pergi ke beberapa daerah di provinsi Sulawesi tenggara. Kota Kendari juga sempat dijuluki kota ruko karena banyaknya ruko yang dibangun dipinggir jalan, walaupun tidak semua ruko tersebut terpakai untuk aktivitas ekonomi.

Dari sisi fasilitas Pendidikan, kota Kendari menjadi magnet buat daerah lainnya yang ada di provinsi Sulawesi tenggara. Kota Kendari juga menjadi tujuan belanja bagi daerah lain yang dekat dengan kota Kendari dan tempat memperdagangkan hasil-hasil pertanian, peternakan maupun perikanan. Hasil penelitian ini dapat dilihat pada tabel 1 dibawah ini tentang struktur ekonomi di kota Kendari.

Tabel 1. Struktur Ekonomi Kota Kendari tahun 2010-2020

\begin{tabular}{|l|r|r|r|r|r|r|r|r|r|r|r|r|r|r|r|r|r|r|r|r|r|r|r|r|r|}
\hline \multicolumn{1}{|c|}{ Lapangan Usaha } & $\mathbf{2 0 1 0}$ & $\mathbf{2 0 1 1}$ & $\mathbf{2 0 1 2}$ & $\mathbf{2 0 1 3}$ & $\mathbf{2 0 1 4}$ & $\mathbf{2 0 1 5}$ & $\mathbf{2 0 1 6}$ & $\mathbf{2 0 1 7}$ & $\mathbf{2 0 1 8}$ & $\mathbf{2 0 1 9}$ & $\mathbf{2 0 2 0}$ \\
\hline A. Pertanian, Kehutanan, dan Perikanan & 12.60 & 11.86 & 11.64 & 11.77 & 11.61 & 11.00 & 11.32 & 11.54 & 12.14 & 12.38 & 12.29 \\
\hline B. Pertambangan dan Pengalian & 1.65 & 1.72 & 2.02 & 2.07 & 2.13 & 2.32 & 2.31 & 2.32 & 2.32 & 2.28 & 2.22 \\
\hline C. Industri Pengolahan & 9.25 & 9.51 & 9.41 & 9.33 & 10.05 & 10.34 & 10.46 & 10.86 & 10.26 & 10.07 & 9.89 \\
\hline D. Pengadaan Listrik dan Gas & 0.11 & 0.10 & 0.11 & 0.10 & 0.11 & 0.11 & 0.11 & 0.12 & 0.12 & 0.12 & 0.12 \\
\hline E. Pengadaan Air, Pengelolaan Sampah, Limbah dan Daur Ulang & 0.32 & 0.29 & 0.30 & 0.31 & 0.32 & 0.31 & 0.30 & 0.27 & 0.26 & 0.25 & 0.24 \\
\hline F. Konstruksi & 15.95 & 17.22 & 18.51 & 18.50 & 18.51 & 19.27 & 19.45 & 18.74 & 19.24 & 19.67 & 19.33 \\
\hline G. Perdagangan Besar dan Eceran; Reparasi... & 16.88 & 17.03 & 16.43 & 16.31 & 16.07 & 16.10 & 16.32 & 16.62 & 16.48 & 16.53 & 16.02 \\
\hline H. Transportasi dan Pergudangan & 9.80 & 9.44 & 9.02 & 8.65 & 8.53 & 8.24 & 7.99 & 7.91 & 8.08 & 8.24 & 8.02 \\
\hline I. Penyediaan Akomodasi dan Makan Minum & 1.12 & 1.24 & 1.35 & 1.35 & 1.31 & 1.35 & 1.29 & 1.30 & 1.27 & 1.23 & 1.17 \\
\hline J. Informasi dan Komunikasi & 8.61 & 7.58 & 7.24 & 7.27 & 6.68 & 6.27 & 6.03 & 6.27 & 6.33 & 6.16 & 6.65 \\
\hline K. Jasa Keuangan dan Asuransi & 5.34 & 5.81 & 6.16 & 6.39 & 6.35 & 6.36 & 6.69 & 6.79 & 6.42 & 6.26 & 6.48 \\
\hline L. Real Estate & 2.75 & 2.56 & 2.46 & 2.31 & 2.11 & 2.04 & 1.87 & 1.82 & 1.71 & 1.64 & 1.65 \\
\hline M,N. Jasa Perusahaan & 0.74 & 0.75 & 0.76 & 0.79 & 0.78 & 0.82 & 0.81 & 0.81 & 0.81 & 0.79 & 0.79 \\
\hline O. Administrasi Pemerintahan, Pertahanan... & 5.91 & 5.76 & 5.31 & 5.24 & 5.49 & 5.21 & 4.76 & 4.61 & 4.62 & 4.54 & 4.79 \\
\hline P. Jasa Pendidikan & 6.46 & 6.57 & 6.50 & 6.83 & 7.09 & 7.36 & 7.52 & 7.35 & 7.35 & 7.38 & 7.78 \\
\hline Q. Jasa Kesehatan dan Kegiatan Sosialt & 1.06 & 1.05 & 1.08 & 1.07 & 1.07 & 1.10 & 1.05 & 1.01 & 1.01 & 1.00 & 1.12 \\
\hline R,S,T,U. Jasa lainnyat & 1.47 & 1.50 & 1.70 & 1.72 & 1.78 & 1.81 & 1.72 & 1.65 & 1.56 & 1.47 & 1.45 \\
\hline
\end{tabular}

Hasil penelitian menunjukkan bahwa struktur ekonomi kota Kendari di dominasi oleh sektor perdagangan besar eceran dan sektor konstruksi. Dimana pada tahun 2010 sektor perdagangan memberi kontribusi terbesar pada PDRB, namun tahun 2020 sektor konstruksi mendominasi kontribusi terhadap PDRB. Sektor konstruksi terdiri dari konstruksi gedung, bangunan sipil dan konstruksi khusus. Sedangkan sektor yang memberi kontribusi terkecil ialah sektor pengadaan listrik dan gas, hal ini dikarenakan kota Kendari tidak memiliki cadangan sumber daya yang terkait dengan sektor tersebut. Lain halnya sektor konstruksi yang memberikan kontribusi terbesar karena kota ini terus melakukan pembangunan fisik maupun perawatan, terlebih lagi dengan adanya wacana menjadikan kota ini menjadi kota metropolitan.

Ada enam sektor yang tetap mengalami peningkatan kontribusi pada PDRB kota Kendari pada masa pandemi ini yaitu sektor informasi dan komunikasi, sektor jasa keuangan dan asuransi, sektor real estate, sektor adminstrasi pemerintahan dan pertahanan, sektor jasa Pendidikan, serta sektor jasa Kesehatan dan kegiatan sosial. Hal ini disebabkan karena pemerintah lebih fokus dalam menangani pandemic covid19 sehingga alokasi anggaran berfokus pada penanggulangan penyebaran virus covid19. Akibatnya terjadi perlambatan ekonomi yang juga mengakibatkan perputaran uang lebih banyak dibidang 
Kesehatan. Sedangkan di sektor lain cenderung statis dan di tambah lagi adanya pembatasan aktivitas yang memaksa masyarakat bekerja dari rumah, bahkan belanjapun dari rumah. Sehingga ada satu bagian dari aktivitas ekonomi baru yang mengalami pertumbuhan positif yaitu e-commerce yang menjadi bagian dari ekonomi baru yaitu ekonomi digital.

Ekonomi digital dapat di artikan sebagai perilaku manusia tentang cara memilih untuk memenuhi kebutuhannya yang tidak terbatas dengan hanya menggunakan jari jemari atau ekonomi digital bisa juga diartikan sebagai aktivitas manusia yang berhubungan dengan produksi, konsumsi dan distribusi dengan menggunakan jari jemari. Pengertian ekonomi digital diatas berarti bahwa manusia tidak perlu lagi ke pasar untuk mendapatkan barang dan jasa, tetapi cukup dengan smartphonenya maka barang sudah bisa sampai dirumah untuk memenuhi keinginannya (Permana dan Puspitaningsih, 2019). Sedangkan dari sisi sektor unggulan yang di kota Kendari sebagai kota jasa adalah sebagaimana di tampilkan pada tabel dibawah ini.

Table 2. LQ Kota Kendari Tahun 2010-2011

\begin{tabular}{|c|c|c|c|c|c|c|c|c|c|c|c|}
\hline \multirow{2}{*}{ Lapangan Usaha } & \multicolumn{11}{|c|}{ LQ } \\
\hline & 2010 & 2011 & 2012 & 2013 & 2014 & 2015 & 2016 & 2017 & 2018 & 2019 & 2020 \\
\hline A. Pertanian, Kehutanan, dan Perikanan & 0.444 & 0.452 & 0.462 & 0.462 & 0.452 & 0.458 & 0.466 & 0.479 & 0.506 & 0.522 & 0.509 \\
\hline B. Pertambangan dan Penggalian & 0.096 & 0.087 & 0.088 & 0.094 & 0.107 & 0.111 & 0.119 & 0.112 & 0.112 & 0.108 & 0.109 \\
\hline C. Industri Pengolahan & 1.386 & 1.450 & 1.571 & 1.584 & 1.684 & 1.737 & 1.712 & 1.770 & 1.665 & 1.573 & 1.405 \\
\hline D. Pengadaan Listrik dan Gas & 2.712 & 2.727 & 2.915 & 2.838 & 2.905 & 2.978 & 2.856 & 2.930 & 2.962 & 2.975 & 2.957 \\
\hline E. Pengadaan Air, Pengelolaan Sampah, Limbah dan Daur Ulang & 1.566 & 1.543 & 1.593 & 1.570 & 1.535 & 1.549 & 1.505 & 1.503 & 1.496 & 1.492 & 1.415 \\
\hline F. Konstruksi & 1.409 & 1.501 & 1.618 & 1.578 & 1.503 & 1.445 & 1.387 & 1.403 & 1.426 & 1.436 & 1.426 \\
\hline G. Perdagangan Besar dan Eceran; Reparasi... & 1.456 & 1.470 & 1.463 & 1.434 & 1.363 & 1.343 & 1.318 & 1.324 & 1.305 & 1.295 & 1.301 \\
\hline H. Transportasi dan Pergudangan & 2.202 & 2.166 & 2.074 & 1.945 & 1.925 & 1.852 & 1.777 & 1.752 & 1.762 & 1.861 & 1.973 \\
\hline I. Penyediaan Akomodasi dan Makan Minum & 2.209 & 2.267 & 2.406 & 2.376 & 2.267 & 2.287 & 2.205 & 2.243 & 2.215 & 2.180 & 2.139 \\
\hline J. Informasi dan Komunikasi & 3.521 & 3.585 & 3.642 & 3.559 & 3.478 & 3.431 & 3.260 & 3.395 & 3.476 & 3.442 & 3.508 \\
\hline K. Jasa Keuangan dan Asuransi & 2.945 & 3.010 & 2.964 & 2.833 & 2.747 & 2.738 & 2.682 & 2.776 & 2.735 & 2.676 & 2.710 \\
\hline L. Real Estate & 1.439 & 1.395 & 1.425 & 1.372 & 1.285 & 1.277 & 1.206 & 1.219 & 1.220 & 1.221 & 1.228 \\
\hline $\mathrm{M}, \mathrm{N}$. Jasa Perusahaan & 3.971 & 3.998 & 4.124 & 4.101 & 3.985 & 3.974 & 3.890 & 3.965 & 3.987 & 3.930 & 3.982 \\
\hline O. Administrasi Pemerintahan, Pertahanan... & 0.907 & 0.914 & 0.937 & 0.923 & 0.908 & 0.916 & 0.887 & 0.894 & 0.908 & 0.927 & 0.926 \\
\hline P. Jasa Pendidikan & 1.436 & 1.476 & 1.568 & 1.606 & 1.556 & 1.619 & 1.601 & 1.619 & 1.630 & 1.649 & 1.666 \\
\hline Q. Jasa Kesehatan dan Kegiatan Sosialt & 1.083 & 1.103 & 1.190 & 1.147 & 1.109 & 1.145 & 1.111 & 1.118 & 1.121 & 1.102 & 1.116 \\
\hline $\mathrm{R}, \mathrm{S}, \mathrm{T}$, U. Jasa lainnyat & 1.105 & 1.131 & 1.288 & 1.293 & 1.280 & 1.299 & 1.258 & 1.271 & 1.238 & 1.206 & 1.209 \\
\hline
\end{tabular}

Dari tabel diatas kita dapat mengetahui bahwa sektor jasa-jasa perusahaan menjadi sektor unggulan dengan nilai LQ tertinggi dari tahun 2010-2020. Sedangkan sektor pertanian maupun pertambangan bukan sektor unggulan dari kota Kendari oleh karena kota Kendari tidak memiliki lahan yang cukup seperti daerah lainnya yang ada di Sulawesi tenggara yang masih merupakan daerah agraris. Sektor jasa-jasa perusahaan terdiri dari aktivitas professional, ilmiah dan teknis, aktivitas penyewaan dan sewa guna usaha tanpa hak opsi, ketenagakerjaan, agen perjalanan dan penunjang usaha lainnya.

Implikasi dari hasil penelitian tersebut bahwa kota Kendari sebagai kota jasa perlu melakukan perubahan pada tata kota yang berhubungan dengan perdagangan. Dan sebagai kota yang memiliki keunggulan di sektor jasa maka perlu dikeluarkan kebijakan yang mendukung peningkatan pelayanan dalam rangka peningkatan nilai kontribusi sektor jasa di kota Kendari mengingat kota Kendari tidak unggul dari sisi pertanian

Sektor jasa-jasa perusahaan, walaupun menjadi sektor unggulan di kota Kendari, namun kontribusinya terhadap PDRB kota Kendari masih sangat kecil. Sehingga perlu adanya upaya peningkatan kontribusi sektor ini pada PDRB. Salah satu yang bisa dilakukan ialah dengan lebih kreatif lagi dalam hal pungutan retribusi. Bagian yang belum dikenakan retribusi agar dipungut retribusinya secara proporsional dan wajib diawasi. Pemanfaatan teknologi bisa dilakukan seperti yang telah dilakukan oleh pemerintah kota yaitu pelayanan jarikendari untuk pelayanan catatan sipil dan laika untuk pelayanan di kelurahan.

Sektor perdagangan juga merupakan sektor unggulan di kota Kendari sebab kota ini menjadi sentra belanja untuk wilayah kota Kendari dan daerah lain di provinsi Sulawesi 
tenggara, walaupun kota lain seperti kolaka dan bau-bau mulai mengalami perkembangan yang cepat, namun sebagai ibu kota provinsi Sulawesi tenggara tetap menjadi primadona dibanding kota lainnya yang ada di Bumi Anoa ini. Dari sisi tata kota perlu adanya penataan kota terutama nama jalan yang masih ada yang sama dan tidak teratur. Harusnya ada pengelompokkan nama jalan agar memudahkan masyarakat terutama pendatang. Seperti ada wilayah yang nama jalan pahlawan, bunga, hewan, maupun pengelompokkan lainnya sehingga tercipta nama Kawasan yang memudahkan masyarakat dalam berpergian dan mencari alamat. Kemudahan dalam mencari alamat juga menjadi faktor pendukung bagi sektor pariwisata.

Akhir dari semua itu ialah pertumbuhan ekonomi yang terus meningkat dan selaras dengan peningkatan kesejahteraan masyarakat. Walaupun anggaran terbatas, tetapi karena adanya alokasi anggaran ke sektor yang unggul maka akan menghasilkan hasil yang maksimal.

\section{Kesimpulan}

Hasil penelitian menunjukkan bahwa struktur ekonomi kota Kendari di dominasi oleh sektor perdagangan besar eceran dan sektor konsttruksi. Dimana pada tahun 2010 sektor perdagangan memberi kontribusi terbesar pada PDRB, namun tahun 2020 sektor konstruksi mendominasi kontribusi terhadap PDRB. Hasil penelitian yang lain juga menunjukkan bahwa sektor jasa-jasa perusahaan menjadi sektor unggulan dari tahun 20102020. Implikasi dari hasil penelitian tersebut bahwa kota Kendari sebagai kota jasa perlu melakukan perubahan pada tata kota yang berhubungan dengan perdagangan. Dan sebagai kota yang memiliki keunggulan di sektor jasa maka perlu dikeluarkan kebijakan yang mendukung peningkatan pelayanan dalam rangka peningkatan nilai kontribusi sektor jasa di kota Kendari mengingat kota Kendari tidak unggul dari sisi pertanian.

\section{Daftar Pustaka}

Arsyad, L. (2017). Ekonomi Pembangunan Dan Pembangunan Ekonomi. Tersedia Secara Online Di: Http://Www. Pustaka. Ut. Ac. Id/Lib/WpContent/Uploads/Pdfmk/ESPA4324-M1. Pdf [Diakses Di Lembang, Jawa Barat, Indonesia: 2 Oktober 2018].

Darwanto, H. (2002). Prinsip Dasar Pembangunan Ekonomi Daerah. Online). Tersedia at bappenas.go.id

Harafah, LM. (2015). Ekonomi Regional: Sektor Basis Dan Unggulan Daerah. Kendari: HISPISI Sultra.

Https://kendarikota.bps.go.id/ diakses Pada 20 Oktober 2021

Https://sultra.bps.go.id/ diakses Pada 20 Oktober 2021

http://perkotaan.bpiw.pu.go.id/v2/kota-sedang/74 diakses pada 7 Desember 2021

Junaidi, J., \& Zulgani, Z. (2011). Peranan Sumberdaya Ekonomi Dalam Pembangunan Ekonomi Daerah. Jurnal Pembangunan Daerah, 3, 27-33.

Permana, T., \& Puspitaningsih, A. Fenomena Uang Digital. Jurnal Ekonomi Pembangunan (Jep) Uho, 9(2), 363-373

Purba, B., Rahmadana, M. F., Basmar, E., Sari, D. P., Klara, A., Damanik, D., ... \& Nugraha, N. A. (2021). Ekonomi Pembangunan. Yayasan Kita Menulis.

Ruda, N. (2015). Ekonomi Pembangunan Islam. Jakarta: Prenadamedia.

Sjafrizal. (2015). Perencanaan Pembangunan Daerah Dalam Era Otonomi. Jakarta: Rajawali Pers. 